\title{
Disinformation and public representations of identity. A feminist close reading of Margaret Atwood's Alias Grace
}

Sara Calvo de Mora Mármol - Universidad de Granada

0000-0002-4740-6580

Adelina Sánchez-Espinosa - Universidad de Granada

D 0000-0001-5872-1431

Recepción: 06.04.2021 | Aceptado: 12.04.2021

Correspondencia a través de ORCID: Sara Calvo de Mora Mármol

0000-0002-4740-6580

Citar: Calvo de Mora Mármol, S y Sánchez-Espinosa, A (2021). Disinformation and public representations of identity. A feminist close reading of Margaret Atwood's Alias Grace. REIDOCREA, 10(19), 1-10. Financiación: Plan Propio de Investigación y Transferencia de la Universidad de Granada (2019): "Beca de Iniciación a la Investigación para estudiantes de Máster"1

\begin{abstract}
While it may be thought that disinformation and 'fake news' are concepts related to contemporary mass media, they are, indeed, much older concerns that have always been part of our society, tracing a media craze path and noticeably blooming nowadays due to the power of the media. This is why it is essential to cultivate critical thinking when approaching journalistic discourses. In this contribution we will employ feminist close reading methods (Lukić and Sánchez, 2011) to examine examples of how newspapers and public opinion can influence and deform a story. We will take Margaret Atwood's Alias Grace (1996) as a case study in order to approach to what an extent its main character is influenced by conflictive opinions which finally determine the performance of her identity. Is being aware of public opinion enough to grant this character control over the self-construction of her image? The conclusions of this paper will include some considerations regarding the use of critical tools such as feminist close reading in the classroom. The case of Alias Grace exemplifies the negative effects of disinformation and ultimately illustrates the transformative potential of critical rewritings of official "HIStories"2".
\end{abstract}

Keywords: Canadian Fiction, Feminist Close Reading

Desinformación y representaciones públicas de la identidad. Una lectura crítica feminista de Alias Grace de Margaret Atwood

Resumen: Si bien la desinformación y las noticias falsas se nos presentan como conceptos relacionados con los medios de masas contemporáneos, en realidad no son un problema nuevo. La práctica periodística de la desinformación siempre ha sido parte de nuestra sociedad y, con más fuerza actualmente, ha marcado nuestras sociedades mediáticas. Es fundamental, por tanto, desarrollar el pensamiento crítico y la capacidad de análisis para transformar dichas sociedades. En este artículo llevaremos a cabo una lectura crítica feminista (Lukić y Sánchez, 2011) de la novela Alias Grace (1996) de Margaret Atwood para estudiar hasta qué punto la historia tergiversada y las opiniones encontradas puede determinar la vivencia y ejercicio de la identidad del personaje principal, Grace Marks. ¿Le basta a Grace estar al tanto de la opinión pública sobre ella para tomar el control de su propia imagen? Las conclusiones de este artículo incluyen observaciones sobre el uso en el aula de herramientas de pensamiento crítico como la lectura crítica feminista. El caso de Alias Grace ilustra tanto las consecuencias negativas de la desinformación como la capacidad transformativa de rescribir las "Historias oficiales"3 desde una perspectiva más crítica.

Palabras clave: Ficción Canadiense, Lectura Crítica Feminista

\footnotetext{
${ }^{1}$ Esta contribución parte de la investigación realizada por Sara Calvo de Mora Mármol bajo la supervisión de Adelina Sánchez Espinosa para el Trabajo de Fin de Máster titulado Servants and peddlers: Multiplicity of identities and the working-class 'other' in Margaret Atwood's Alias Grace, defendido en julio de 2019. El presente artículo extiende las conclusiones de dicho trabajo explorando sus implicaciones metodológicas y es uno de los resultados de la beca de iniciación a la investigación que actualmente continúa en forma de investigación predoctoral.

${ }^{2}$ We are using "HIStories" in opposition to "HERstories" following the prevalence of the latter within feminist cultural criticism. "Herstory" was first used by Robin Morgan in her now classic "Goodbye to all that" (1970) and has become current use ever since. ${ }^{3}$ El doble sentido de este término en inglés, las historias de ellos frente a las de ellas, se pierde al traducirlo al español. Ver nota

1 para más información al respecto.
} 


\section{Introduction. "Just because a thing has been written down, Sir, does not mean it is God's truth" (AG, 1996, p. 299)}

With the above statement, Margaret Atwood addresses an issue that was a concern when her story takes place and is still troubling us today: the spread of disinformation through newspapers, journals, literature and, lately, through mass media such as television, the radio or the Internet. The frequent disregard for truth and honest information on the media has become utterly disturbing nowadays. UNESCO, for instance, has recently published a Handbook (2018) with which they respond to the "emerging global problem of disinformation that confronts societies in general, and journalism in particular" (UNESCO, p. 7). The text sets the difference between "misinformation" and "disinformation", the former defined as "misleading information created or disseminated without manipulative or malicious intent" while the latter involves the "deliberate (often orchestrated) attempts to confuse or manipulate people through delivering dishonest information to them" (UNESCO, p. 7). They carry on discussing the magnitude of this problem by arguing that the public will eventually believe whatever their social networks tell them (UNESCO, p. 9). Simply writing "post-truth" and "media" on a search engine produces more than a million hits that link to articles and opinion columns referring to the current socio-political situation with allusions to "fake news" or Trumpisms such as "alternative facts". These negative repercussions of the so-called "fake news" could, however, be partially challenged by taking a critical approach towards what we read and hear.

Certainly, this social problem is not new at all. Manipulation through the news goes back to the beginning of history. And when the subject under scrutiny is a woman, we must remember that one of the most recurrent patriarchal strategies to counteract women power has been the deformation or even total silencing of their life stories. Newspapers, literature and even "official Histories" have omitted or consciously changed the tale told of women's lives in order to comply with the social norms dictated by patriarchy throughout the centuries.

Focusing on the period that occupies our study, many have been the approaches to how women have been mistreated by the press in the 19th century, some of which we would like to briefly highlight before moving onto the analysis of our case study. Women, Periodicals and Print Culture in Britain, 1830s-1900s: The Victorian Period (2019), for instance, compiles chapters devoted to the depiction of women in the Victorian press in Britain, Ireland and Wales. Together with this, Twisting in the Wind: The English Murderess and the English Press (1998), and "Class and Gender Bias in Victorian Newspapers" (1993), both by Judith Knelman, address the issue of the press representation of Victorian women criminals. Knelman analyses the restrictive social standards and the discrimination which may have pushed women towards crime and advances her thesis that their crime stories were magnified in order to make these women appear as even more gruesome and monstrous.

Turning now to the case study of this article, the indisputable weight of Margaret Atwood's influence upon contemporary literature is worth mentioning, being, as she is, a writer and a feminist whose novels and lectures vindicate a change in current mindsets and someone who has become worldwide famous thanks to the media, particularly the Hulu adaptation of her The Handmaid's Tale in 2017. In the case that occupies this article, Alias Grace (1996), Margaret Atwood gives her voice back to a Victorian woman, Grace Marks, who was silenced in her times. Grace's story was deformed by the patriarchal gaze of her times and her character was turned into either a demon or an angel, depending on who was asked. It is the thesis of this article that Margaret Atwood

${ }^{4}$ All references to Alias Grace in this article are abbreviated to $A G$. 
conceived this novel as an interrogation about the character's official history. In so doing the novel opens up a general questioning on the veracity of other "official histories" as well. In order to debate historicity, Atwood turns to official sources at the time and to what contemporary authors wrote about Grace.

The overall perspective of this article is feminist. Our intention is the exploration of 19th century young women's control of their identities over the public constructions of their images. Our research could easily be transposed to current times, as we propose in what follows. We will finish the article with comments on the pedagogical implications of these issues.

\section{Methodology}

This article is the result of a long period of full immersion in Margaret Atwood's fiction and on critical literature on both the author and her novel Alias Grace, focusing on manifold perspectives from trauma studies to postcolonial theories ${ }^{5}$.This article, however, attempts a different approach, carrying out a feminist close reading of the novel. The aim with this type of analysis is both to study the text in itself and the social reality that it represents, which plays an essential role in the novel.

In their chapter "Feminist perspectives on close reading", Jasmina Lukić and Adelina Sánchez Espinosa (2011) offer a brief review of how close reading as a method has changed throughout the years, pointing out that, while at the beginning this method concentrated on the structures of the text itself, new feminist perspectives have diverted attention from the text to the context and revamped the method as a very useful feminist tool to establish connections between those literary structures and the social context in which they were produced. They argue that awareness of the interplay of such relations, would allow the reader to access the underlying meanings of the text. More particularly, they propose that this renewed type of close reading includes aspects such as gender, race or class in the analysis of the text. These aspects are part of the reality of novels in their context, which is why it is essential to take them into account when interpreting a text. The text exists in various contexts: either that of the writer or that of the reader, or even a combination of both. The analysis of these contexts would allow a much more comprehensive understanding of the text.

Lukić and Sánchez further develop their arguments by quoting Sara Mills (1995), for whom reading is a process in which one must start by questioning the text in order to identify the "different ways in which sexism works in language" and then "propose strategies to oppose it" (Lukić and Sánchez, p. 165). In addition, they refer to Peggy Kamuf's (1980) contributions by discussing the advantages of deconstructionist practices for feminist close reading since they offer "multiple, indeterminate meanings" (Lukić and Sánchez 166) of the text, allowing the critic to access different readings or interpretations of the same text.

Another influential methodological approach is Adrienne Rich's concept of a feminist revision of history (1972). Her objective of breaking with the past for women to be able to think for themselves, instead of blindly accepting patriarchal notions of history, is essential in any critical feminist analysis. In fact, in many cases, it goes perfectly hand in hand with feminist close readings, which is why we are adopting both approaches in the development of this study.

\footnotetext{
${ }^{5}$ Using Stef Craps (2013) and Gayatri Spivak (1994) respectively, among many others.
} 
By resorting to feminist close reading as our method, we have been able to analyse parts of the novel in their context and with an eye on unveiling its underlying meanings. Thus, the texts analysed are extended in the sense that we have not limited our study to the fictional account of the story narrated but have also included the various epigraphs which appear before each section of the novel and the Author's Afterword. Other companion sources have also been read alongside this extended text.

\section{Margaret Atwood's Alias Grace: A case study}

In this novel, Margaret Atwood presents the reader with a fictional account of a notorious real-life crime that took place in 1843 in Canada. The protagonist of this event was Grace Marks, an Irish immigrant who was barely sixteen years old at the time of the crimes. Grace and her co-worker, another young servant named James McDermott, were accused of a double murder, that of their employer Mr Thomas Kinnear, and of his housekeeper, Nancy Montgomery. Even though these facts are based on true events, Atwood fictionalizes this story and decides to introduce new characters, such as a Simon Jordan, a "doctor who works not with bodies, but with minds" ( $A G$, p. 45), to make it more complex. Using pre-Freudian techniques of psychoanalysis Doctor Jordan tries to recover Grace's memories to assess whether she is indeed mentally ill or whether she is simply a manipulative woman, guilty of the crimes she has been accused of. The story shows Grace's many traumatic experiences during her childhood and early life, and illustrates how trauma has affected her, shaping her mind. The mastery of Atwood's narrative consists on transmitting a feeling of understanding to the readers without allowing for a final sense of enlightenment when the novel concludes.

Back in 1998, Margaret Atwood said, "we live in a period in which memory of all kinds, including the sort of larger memory we call history, is being called into question" (p. 1505). This statement has become all the more relevant in the last few years, given our coexistence with "alternative facts" and "post-truths". Indeed, the need for historical revisions and re-evaluations of given stories has grown exponentially. Although feminist interventions have been essential in order to help us re-interpret our own stories by offering revisions of the dominant patriarchal readings of classic texts, the tremendous growth of ITs is making the feminist task harder and harder. Confronted with the free access to a quasi-infinite number of versions and sources which can, in turn, be tampered with, which one do we take? How do we position ourselves? Which one is the right option? We obviously need new instruments to deal with this situation. When it comes to reading, we, critical scholars and teachers, need to produce toolboxes which can guide readers and help them evaluate the validity of what they are offered.

This statement goes in line with Atwood's idea that "although there undoubtedly was a truth [in Grace' story] truth is sometimes unknowable, at least by us" (1998, p. 1515). Atwood argues in the afterword that she has fictionalized historical events, but that so "did many commentators on this case who claimed to be writing history" (p. 541). In fact, this premise can be observed in many of her texts, such as Alias Grace itself, The Penelopiad (2005) or The Robber Bride (1993), to name but a few. Whether they are set in the past or in the present, her texts question the official stories we were told about the past and they offer counter-narratives of the "facts". Given the falsity of official stories in Atwood's view, other fictional elements can be added to their re-telling with just as much validity as the original narrative acted upon. In their subversive contestation of current visions of society, Margaret Atwood's novels hence call for equally subversive critical methodologies of analysis such as feminist close reading.

Historical and literary revision are Atwood's means to achieve female empowerment in Alias Grace. This novel falls into the category of historiographic metafiction, Linda 
Hutcheon's concept (1988) which could be defined, as the name plainly suggests, as a combination of metafiction and historical fiction which, in Hutcheon's words, "problematizes the very possibility of historical knowledge, because there is no reconciliation, no dialectic here- just unresolved contradiction" (p. 106). In Alias Grace this problematization is attained by Atwood's use of historical sources from the mid1800 s, when the story took place: journal excerpts; the confessions of the accused, James McDermott and Grace Marks; fragments from the Kingston Penitentiary's Warden daybook; and, above all, fragments from Susanna Moodie's ${ }^{6}$ account of Grace's story in her Life in the Clearings (1853). These documents create a tacit dialogue with Atwood's fictionalisation of Grace's story and the resulting polyphony ultimately makes the reader reconsider the veracity of certain deep-rooted historical opinions.

\section{The Aliases in Grace. A feminist close reading}

The very title of the novel, Alias Grace, foreshadows the fact that there is more than one Grace Marks and the question that emerges from this is whether we have ever known, or could ever get to know, the real Grace. The different versions of her story are sometimes contradictory, which correlates with the division of opinions and the real controversy that surrounded Grace Marks's case back in the 1800s. Public opinion was divided at the time. Some believed her to be the victim of a man's desire and ambition and thought that James McDermott had pushed her to commit the crimes. Then there were those who considered her an "inhuman female demon" (AG, p. 25). Margaret Atwood affirms in the afterword that much was written about Grace Marks and that "attitudes towards her reflected the contemporary ambiguity about the nature of women" (AG, p. 538). While Grace Marks was a Victorian woman, the author has written this novel in the twentieth century which means that, as Gillian Siddall (2004) puts it, Atwood's Grace has "anachronistically, access to postmodernist conventions that allow her to construct her life story in a way that challenges essentialist notions of identity" ( $p$. 85). Besides Siddall, other critics such as Judith Knelman (1999) or Fiona Tolan (2007) have pointed out the anachronisms and the postmodernism of Atwood's text: "We have here [...] a misleading and indeed anachronistic reconstruction of nineteenth-century theories about multiple personality" (Knelman, p. 682). Grace becomes complex due to the re-visionary approach to history that Atwood adopts in her novel, introducing new perspectives that resurrect silenced voices.

This character's complexity is unquestionable. The aforementioned postmodernist approach in this story explains the depth with which Atwood has managed to portray a $19^{\text {th }}$ century maid about whom we know so little. Taking as much information as she can from the historical sources which she includes in her novel, and questioning their veracity, the author presents a woman whose life has gone from misery to misery. Although Grace is uneducated, her understanding of life is unusually sophisticated. This contradicts the higher-class opinion of Victorian servants as "simple, unintelligent and needing guidance as if they were children" (Braid, 2011, p. 232). We see in some instances that Grace also possesses a detailed knowledge of the Bible: "I know it is in the book of Job" (AG, p. 43), "I knew my Bible backwards and forwards" ( $A G$, p. 258). This was not uncommon in the $19^{\text {th }}$ century, but it is worth mentioning that this knowledge seems to help her better understand the underlying meanings of what Dr Jordan says to her: "He must mean that he has come to test me" ( $A G 43)$, "He's playing a guessing game [...] There is always a right answer, which is right because it is the one, they want" (AG, p. 45).

\footnotetext{
${ }^{6}$ Susanna Moodie's, Life in the Clearings (1853) is one of Atwood's main sources of inspiration for her novel. It includes a chapter named after Grace Marks in which Moodie describes Grace's story and her encounters with her in the Asylum and in Kingston Penitentiary.
} 
At this point we question to what an extent is Atwood trying to provide us with a historically accurate depiction of Grace and the crimes. As she says in the Author's Afterword, when in doubt, she "tried to choose the most likely possibility" (AG, p. 542) and she "felt free to invent" ( $A G$, p. 542) where she found historical gaps. However, Judith Knelman (1999) argues that, while Atwood implies that the press "failed Grace by sensationalizing and politicizing her case" (p. 677), this was "possible, but unlikely" ( $p$. 677). In her article "Can We Believe What the Newspapers Tell Us?: Missing Links in Alias Grace" (1999), Knelman offers an analysis of Alias Grace in which she claims that Atwood constructed the novel in a "skewed, fragmented" way that "make[s] sense in Atwood's scheme of things" (p. 683) and how she wanted Grace to be perceived by the reader.

The point is that Grace's story has been discussed and altered by so many people, including Atwood, that it has become something else to whatever its original version was. The voices from newspapers, lawyers and public opinion in general have all participated in the creation of an individual who they have forged either as Grace Marks the criminal or Grace Marks the victim. The many fragments which open the various parts of the novel illustrate the polyphony that Atwood recreates. "She looks like a person rather above her humble station", said Susanna Moodie in Life in the Clearings (AG, p. 21); "Grace was of a lively disposition and pleasant manners and may have been an object of jealousy to Nancy", shared William Harrison with the Newmarket Era, 1908 (AG, p. 213); finally, in his confession, James McDermott said that "Grace was very jealous of the difference made between her and the housekeeper, whom she hated, and to whom she was often very insolent and saucy" ( $A G$, p. 273).

\section{Public views and constructions of Grace's identity}

In the third chapter, Grace describes what she sees when she looks at herself in the mirror, which is a composite description using everything that is said about her:

I think of all the things that have been written about me - that I am an inhuman female demon, that I am an innocent victim of a blackguard forced against my will and in danger of my own life, that I was too ignorant to know how to act and that to hang me would be judicial murder, that I am fond of animals, that I am very handsome with a brilliant complexion, that I have blue eyes, that I have green eyes, that I have auburn and also brown hair, that I am tall and also not above the average height, that I am well and decently dressed, that I robbed a dead woman to appear so, that I am brisk and smart about my work, that I am of a sullen disposition with a quarrelsome temper, that I have the appearance of a person rather above my humble station, that I am a good girl with a pliable nature and no harm is told of me, that I am cunning and devious, that I am soft in the head and little better than an idiot. (AG, p. 25)

All of this makes the readers ask themselves the same thing Grace asks herself: "how can I be all of these different things at once?" (AG, p. 25). What is interesting of this passage is the obvious awareness that Grace has of the construction of her identity by others. Although she is fully conscious of how she is viewed and how this could affect her own performance of the self, she seems to lack the chance to change or even influence upon this construction, seems being the key word. So, the question is, does she really lack the means to influence this construction?

Margaret Atwood asks herself about the reliability of memory, both individual and collective as a society, when she approaches Grace's story. She realises that there was an audience for every version of Grace's story and that both story and public were shaped by a myriad of opinions about "politics, and also about criminality and its proper treatment, about the nature of women - their weakness and seductive qualities" (Atwood, 
1998, p. 1514). In the opinion of Gillian Siddall, which this article shares, Alias Grace's overriding consideration is not the notion of authentic identity, but rather, the complexity of the politics of "self-representation of a woman oppressed by public discourses of gender, class, and ethnicity" (2004, p. 85).

In fact, we could argue that Atwood has created a character who defies any notion about her, while also suffering the consequences of this public construction of her identity. Sara Minaj (2019) $)^{8}$ posits that the language used in Alias Grace $^{9}$ is related to the duplicity in Grace and her subordination/opposition to patriarchal standards. She argues that for Grace, "regardless of the truthfulness of her testimony, her lack of power and inability to speak through the patriarchal language would always result in 'wrong words' and in a twisted version of her story" (Minaj, p. 4).

Much like Grace herself, Atwood is aware of the multiplicity of versions of this character, and she knows how to critically look at them, including them in her novel only to call them into question. These different versions of the story necessarily call for oppositional close readings both of the novel and of the historical events upon which it is based. Oppositional and subversive readings allow us to question the information that we are fed with by the media, literature or "official histories". It is up to the critical reader to find the gaps and to question what they are being told. "Atwood imposes causal shape on the past" (Knelman, 1999, p. 684) and this is not so different from what others did, and still do, when recounting certain events.

"Within the silences of this case seems to lurk the meaning of her ordeal" (Knelman, 1999 , p. 681). Indeed, as Knelman observes, there are silences in this story that allude to the truth -a truth which was most likely known only to Grace herself. And this fact is key to this analysis. The manner in which Atwood recreates this woman evinces the fact that Grace controlled a very important element: her own identity performance. She decides what to share and what to withhold. She suffered greatly at the beginning of her imprisonment because she exteriorised her anger and trauma: "[as long as you] do not lose control of yourself and become violent, you shall remain as you were" ( $A G$, p. 46). This could mean that she had lost control before and consequently, she was sent to the Lunatic Asylum in Toronto. On this topic Knelman (1999) points out that apparently the real Grace mobilised some of the other prisoners to support her protests, which would explain her being sent away from prison. She does not do this in the novel and, by remaining almost invisible in the Penitentiary, by being "a model prisoner, and giv[ing] no trouble" ( $A G$, p. 5), she refuses to play any of the roles assigned to her by public opinion.

What this all means is that she does, in fact, have the means to influence the constructions of her identity. This answer to the question we posed earlier on in this essay is particularly relevant. While it is almost self-evident in the novel, we cannot access the reality of the case and do not know whether the true Grace Marks acted one way or another in order to support, refuse or ignore the public constructions of her identity. The fictional Grace, on the other hand, performs a personality that charms the doctor and the committee working on her release. It may not be the general public, but it is the most significant public, the one she needs to convince in order to be acquitted.

\footnotetext{
${ }^{7}$ In the $19^{\text {th }}$ century the Irish were racialized by the British, who considered them inferior. This vision of Irish people as non-white continued to take place in colonised lands such as North America, which is why gender, class and race all influence, Grace.

${ }^{8}$ Her paper "Alias Grace: Defying the Male Gaze and Rhizomatic Knowledge" has not been published. The date provided refers to when it was uploaded on Academia.edu.

${ }^{9}$ She focuses her analysis on the audiovisual adaptation of the novel, but her results are relevant for this particular textual analysis as well.
} 
Siddall (2004) addresses this issue by looking at Alias Grace under the light of Atwood's "In Search of Alias Grace" (1998): "An important part of her character in the novel is the extent to which she is aware of the lack of control she has over the public representation of her identity" (Siddall, p. 130). Here we dissent from Siddall since we believe that Atwood's Grace works towards influencing her public identity. She does not let Doctor Jordan, or the reader for that matter, truly get to know her, despite his being a renowned psychologist with his own techniques to extract information from patients. In fact, she is aware of what is said about her and she questions it, but it is not her true identity, which is safe from public opinion and judgement. The fictional Grace seems coy and harmless: according to Dr Jordan, she is "a nun in a cloister, a maiden in a towered dungeon" ( $A G$, p. 68). However, she is also intelligent, and her eyes are "far from insane" (AG, p. 68). All in all, the doctor feels "as if it were he, and not she, who was under scrutiny" ( $A G, p$. $68)$.

This fact is noteworthy because it shows the strength of an oppressed woman who does not completely surrender to social influences. Margaret Atwood claims that "each character in fiction has an individual life, replete with personal detail [...] but each also exists within a context" (1998, p. 1504). We could argue that her apparent intention to provide us with a realistic depiction of a person, giving Grace an "individual life", seems to be successfully achieved with these interventions.

Passages like the one quoted above are frequent in the novel and they give the reader the illusion of a seemingly deep understanding of Grace's thoughts, only to later make them doubt everything. It is our opinion that this orality and naturality in Grace's interventions and thoughts form a more faithful depiction of a real individual's mind. Instances of this are the remarkable lack of periods in Grace's thoughts and dialogues such as the passage quoted above. This use of polysyndeton gives the text the fluidity of a natural thought process, as if we were truly hearing Grace think these words. The use of anaphora as a rhetorical device throughout the paragraph is yet another example of orality in the written text. Grace incessantly repeats the same structure at the beginning of her sentences: "that I am", "that I was", "that I have", and so on. These features give texture to the text, making it more life-like and perhaps even making the reader feel more sympathetic towards Grace. As Hilde Staels argues, Grace's "sense of existence depends on being heard" (2000, p. 444).

Indeed, this orality sharply contrasts with the solidity of the written word, of "official histories", and it adds to the recovery of "silenced" voices and the re-vision of history, which allows individuals such as Grace to tell their own story, however fictional this account may be. Grace is given a voice with recognisable characteristics and this brings her arguably closer to the reader's experience. However, in turn, this damages her own reliability as a narrator. "In telling her own story, Grace manages to be both a unified authority and a patchwork of voices" (Tolan, p. 224). This polyphony is connected to the sphere of the multiplicity of versions, opinions and voices that comment on a particular event. In these alternative versions of a single story, we should ask ourselves if there is one single truth, or if each of the different opinions holds is own truth.

\section{Conclusions and some pedagogical considerations}

The fact that this novel and its author have been subject to thorough analysis from very many different perspectives has finally worked as an advantage since we have been able to look at those sources critically and assess their validity and utility for our research.

The newspapers from the $19^{\text {th }}$ century, the broadsides that showed Grace Marks's case and trial, this novel and even the play on this subject, all contribute to creating public 
opinion. Whether the real Grace managed to overcome these constructions or whether she was changed by them, we cannot know from a novel or a newspaper's article. After thorough analysis, we have argued that Grace can control her own identity performance and by taking control of this aspect of herself, she can even influence public opinion, as proved by how she convinces the committee to finally release her.

It is our hope that the conclusions of this article can be extrapolated not only to other texts but also to other areas of knowledge. For instance, the use of close reading from a feminist perspective is a starting point from which much research in the fields of literature and education should begin. Sánchez and Lukić's view of close reading as a feminist tool with which to critically look at texts becomes paramount in our current context with the increasing need of critical analysis skills in order to teach students to read between the lines and be able to find their voice among the global noise of postrumpism.

Oppositional close-readings and historical re-visions as lenses through which to look at literature are an interesting tool for the classroom as well. Students should be able to do more than simply skim through the pages of a book, they should be able to take a step back and critically reappraise the text, questioning what they read and posing the necessary questions to enjoy its full complexity. They should be trained to analyse the text in its context. In short, the type of analysis that we have carried out in this article is but a mere example of what could be done in our classrooms to create more ethically conscious students who can later apply these in a myriad aspect of their lives. They could then dissect hegemonic patriarchal structures that keep society from progressing in many respects and generate their own response-able attitudes. Alias Grace is but a case study with which to illustrate the social critique that underlies many literary texts and the potential of literature as a transformative technology in current society.

\section{References}

Atwood, Margaret. (1996) Alias Grace. London: Bloomsbury.

—. (1998). In Search of Alias Grace: On Writing Canadian Historical Fiction, The American Historical Review, 103(5), 1503-1516. Retrieved from www.jstor.org/stable/2649966.

Braid, Barbara. (2011). The Other World Under the Stairs: The Victorian Female Servant in the Neo-Victorian Novel. In A. Gonerko, M. Sokół, J. Witkowska, U. Zagratzki (Eds.) Us and Them - Them and Us: Constructions of the Other in Cultural Stereotypes (231-246). Aachen: Shaker Verlag.

Craps, Stef. (2013). Postcolonial Witnessing: Trauma Out of Bounds. Palgrave Macmillan. Easley, A., Gill, C., Rodgers, B. (Eds.). (2019) Women, Periodicals and Print Culture in Britain, 1830s-1900s: The Victorian Period. Edinburgh University Press.

Hutcheon, Linda. (1988) A Poetics of Postmodernism. History, Theory, Fiction. London: Routledge.

Journalism, 'Fake News' \& Disinformation. Handbook for Journalism Education and Training. UNESCO, 2018.

Kamuf, Peggy. (1980) Writing like a woman. In R. Borker, McConnell-Ginet, S. and N. Furman (Eds.) Women and Language in Literature and Society (284-289). Praeger Publishers.
Knelman, Judith (1999). Can We Believe What the Newspapers Tell Us?: Missing Links in Alias Grace. University of Toronto Quarterly, 68(2), 677-686.

-. (1993). Class and Gender Bias in Victorian Newspapers, Victorian Periodicals Review, 26(1), 29-35. Retrieved from https://www.jstor.org/stable/20082645

-. (1998) Twisting in the Wind: The Murderess and the English Press. University of Toronto Press.

Lukić, Jasmina and Sánchez Espinosa, Adelina. (2012) Feminist Perspectives on Close Reading. In R. Buikema, G. Griffin and N. Lykke Theories and Methodologies in Postgraduate Feminist Research: Researching Differently (105-118). Routledge.

Mills, Sara. (1995). Feminist Stylistics. London and New York: Routledge.

Minaj, Sara. (2019) Defying the Male Gaze and Rhizomatic Knowledge. Alma Mater Studiorum, University of Bologna. Unpublished manuscript.

Moodie, Susanna. (1853) Life in the Clearings versus the Bush. Macmillan of Canada, 1976.

Morgan, Robin (1970). "Goodbye to All That" Rat Subterranean News, February 6, 6-7. 
Rich, Adrienne. (1972) When We Dead Awaken: Writing as ReVision. College English, 34(1), 18-30.

Siddall, Gillian. (2004) 'That is what I told Dr. Jordan...': Public Constructions and Private Disruptions in Margaret Atwood's Alias Grace. Essays on Canadian Writing, 81, 84-102.

Spivak, Gayatri Chakravorty. (1994). Can the Subaltern Speak? In P. Williams, L. Chrisman (Eds.) Colonial Discourse and PostColonial Theory: A Reader (66-111). Columbia University Press.

Staels, Hilde. (2000). Intertexts of Atwood's Alias Grace. Modern Fiction Studies, 46(2), 427-450

Tolan, Fiona. (2007). Margaret Atwood: Feminism and Fiction. Amsterdam - New York: Rodopi B. V. 